This item was submitted to Loughborough's Research Repository by the author.

Items in Figshare are protected by copyright, with all rights reserved, unless otherwise indicated.

\title{
Future engineers: the intrinsic technology motivation of secondary school pupils
}

PLEASE CITE THE PUBLISHED VERSION

http://dx.doi.org/10.1080/03043797.2017.1387100

PUBLISHER

Taylor \& Francis @ SEFI

VERSION

AM (Accepted Manuscript)

\section{PUBLISHER STATEMENT}

This work is made available according to the conditions of the Creative Commons Attribution-NonCommercialNoDerivatives 4.0 International (CC BY-NC-ND 4.0) licence. Full details of this licence are available at: https://creativecommons.org/licenses/by-nc-nd/4.0/

\section{LICENCE}

CC BY-NC-ND 4.0

\section{REPOSITORY RECORD}

Jones, Lewis, Hilary McDermott, John Tyrer, and Nigel P. Zanker. 2019. "Future Engineers: The Intrinsic Technology Motivation of Secondary School Pupils”. figshare. https://hdl.handle.net/2134/26723. 


\section{Future Engineers: The Intrinsic Technology Motivation of Secondary School Pupils}

Lewis C.R. Jones ${ }^{(a)}$, Hilary J. McDermott ${ }^{(b)}$, John R. Tyrer ${ }^{(a)}$ \& Nigel P. Zanker $^{(c)}$

${ }^{(a)}$ Wolfson School of Mechanical, Electrical and Manufacturing Engineering, Loughborough University, UK

${ }^{(b)}$ School of Sport, Exercise and Health Sciences, Loughborough University, UK

${ }^{(c)}$ Loughborough Design School, Loughborough University, UK

Corresponding author. Dr Lewis Jones, Wolfson School of Mechanical, Electrical and Manufacturing Engineering, Loughborough University, Loughborough, Leicestershire, LE11 3TU, UK. Email: L.Jones@lboro.ac.uk. 


\section{Future Engineers: The Intrinsic Technology Motivation of Secondary School Pupils}

The supply of students motivated to study engineering in higher education is critical to the sector. Results are presented from the 'Mindsets STEM Enhancement Project'. Fifty-seven new resources packs, designed to improve STEM education in Design and Technology, were given to schools across London. A modified Intrinsic Motivation Inventory questionnaire measured pupils' ( $n=458)$ motivation towards technology. The results show that although pupils have positive reactions to the technology content within Design and Technology lessons, the type of STEM resources and lessons created through the project had made no significant difference on pupils' interest/enjoyment towards technology. This suggests standalone resources do not improve pupil motivation. The impact of this work to engineering higher education is that the existing levels and the inability to improve pupil motivation in technology at school could be a factor affecting the pursuit of a technology or engineering related education or career.

Keywords: Motivation for learning, Engineering Education, STEM, Design and Technology, Secondary School.

Word Count: 4688

\section{Introduction}

There is an increasing need for individuals with the knowledge and skills taught within the Science, Technology, Engineering and Mathematics (STEM) subjects within UK industry (Atkins, 2015; Harrison, 2012; IMechE, 2011; Roberts, 2002). STEM education is in demand. A holistic STEM education provides pupils with an increased understanding of how things work and improves their use of technology (Bybee, 2010). Technology is a crucial part of STEM and pupils’ use of technology can help with innovation, inspiration and creativity (Beyers, 2010; Bull \& Garofalo, 2009; Eisenberg et al., 2003). Technology education can also improve performance and perceptions of 
science and maths (Alexander, Tillman, Cohen, Ducamp, \& Kjellstrom, 2013; Lamberty, 2008). However, the supply of STEM educated pupils from England's secondary schools does not meet the demand from higher education and engineering industry.

The teaching of Mathematics and Science is clearly evident in the English School Curriculum; however, this cannot be said for Technology and Engineering. Whilst elements of these subjects can be found in Computing, Design and Technology (D\&T), Information and Communications Technology (ICT) and Physics, they are not clearly defined as their own disciplines within the national curriculum. There are declining numbers of pupils choosing to study technology subjects beyond compulsory education, at GCE A-Level (JCQ CIC, 2014; Jones, 2016). Growth of engineering and technology subjects is slow, compared to all other subjects, in higher education (HESA, 2014; Matthews, 2014). Three decades of initiatives to increase the number of women in physics and engineering has made little impact (Smith, 2011), with women still only representing 13\% of the STEM workforce (Botcherby \& Buckner, 2012). The research presented in this paper was driven to analyse pupils' engagement, or disengagement, with STEM to understand the negative records for the supply of pupils, in contrast to the positive growth in demand from industry.

Key Stage 3 (KS3) D\&T was chosen as the most appropriate area of investigation for this research due to the decline in technology compared to mathematics and science education. In addition, D\&T contains the largest amount of technology content in the compulsory curriculum, and therefore could provide the greatest insight and largest effect (Department for Education, 2013).

There are issues with the technology content within D\&T. The key findings in reports from the Office for Standards in Education, Children's Services and Skills 
(Ofsted) identified a lack of relevant expertise in secondary school D\&T teachers for the broad range of technology content within D\&T (Ofsted, 2008, 2011b). Common projects and technology focused lessons are most suited to Craft Design and Technology (CDT) rather than technology rich learning intended for modern D\&T (Barlex \& Rutland, 2008; Cox, 2007; Kimbell, 1994; Lewis, Baldwin, Dein, \& Grover, 2005; Zanker, 2005). With teachers having difficulty implementing new technology projects (Choulerton, 2015; Jones, Tyrer, \& Zanker, 2013; Musta’amal, Norman, \& Hodgson, 2009; Ofsted, 2011b).

The 'Enhancing the teaching of STEM through Design and Technology (Mindsets STEM Enhancement Project)' programme was created and managed by the Design and Technology Association to provide schools with financial support and resources focused on improving the technology content of D\&T lessons. This paper presents results of the research conducted to measure outcomes. The motivation of pupils was selected as an appropriate outcome measurement to identify pupils’ engagement with technology lessons and resources.

Self Determination Theory is a broad framework for the theory of motivation that was established by Deci and Ryan (1985). It introduced the idea of intrinsic and extrinsic motivation. In education intrinsic pupil motivation is learning for their own benefit, while extrinsic motivation is driven by the desire to pass exams (Deci \& Ryan, 2000; Ryan \& Deci, 2000a, 2000b). The theoretical framework of intrinsic motivation has been used in this research as a indicator of student engagement and learning with technology. This is because intrinsic motivation has been associated with better academic performance in school (Cordova \& Lepper, 1996; Gillet, Vallerand, \& Lafrenière, 2012; Kusurkar, Ten Cate, Vos, Westers, \& Croiset, 2013; Lin, McKeachie, \& Kim, 2003; Uyulgan \& Akkuzu, 2014). Links have also been shown between deep 
learning and intrinsic motivation (Chin \& Brown, 2000; Marton \& Säljö, 2005;

Warburton, 2003) all of which would contribute to improved student learning and engagement.

The specific aims of this study were to:

(1) Measure the baseline intrinsic motivation of Key Stage 3 Design and Technology pupils have towards technology.

(2) Assess the effect of a range of STEM resources had on pupils' intrinsic motivation towards technology.

The resources given to schools by the Design and Technology Association were intended to make technology education more engaging. The resources were practical based design activities and experiments, each one focused on one area of the technology portion of the D\&T national curriculum. This was to give pupils hands on experience with equipment such as programmable devices, electronic circuits for simple electrical products and smart materials. Details of resources can be found at https://www.data.org.uk/for-education/secondary/stem-into-action-with-dt/.

\section{Method}

\section{Design of Pupil Questionnaire}

To assess the motivation of pupils in this study the Intrinsic Motivation Inventory (IMI) was used, (http://www.selfdeterminationtheory.org). The IMI questionnaire is a multidimensional instrument containing subscales of interest/enjoyment, perceived competence, effort, value/usefulness, felt pressure and tension, perceived choice while performing a given activity and experiences of relatedness. The instrument has been used in prior research (Deci, Eghrari, Patrick, \& Leone, 1994; Plant \& Ryan, 1985; 
Ryan, 1982; Ryan, Connell, \& Plant, 1990; Ryan, Koestner, \& Deci, 1991) and

specifically in measuring pupils in educational research (Loukomies et al., 2013;

Sproule et al., 2013; Vaino, Holbrook, \& Rannikmäe, 2012). These studies report on the reliability of the developed scales.

Three of the subscales were chosen for use in this study interest/enjoyment, perceived competence and pressure/tension. The interest/enjoyment subscale is the selfreport measure of intrinsic motivation and contains 7 items. The perceived competence subscale is a positive predictor of intrinsic motivation and contains 6 items.

Pressure/tension is a negative predictor of intrinsic motivation and contains 5 items. It is expected that there will be correlation between the factors and to provide validation between factors.

The original IMI questionnaire is generic and it recommended by the authors of the instrument that it is modified to suit the individual study. The questionnaire has therefore been modified so that the items assess pupils’ perceptions of technology projects in D\&T. Below is an example of one modified item:

- Original statement: "I thought this was a boring activity"

- Modified statement for start of project: "I think that technology projects are boring.”

- Modified statement for end of project: “I thought that this technology project was boring.”

The use of multiple items will improve the reliability of the three subscales. Pupils rate their agreement to each of the 18 items on a 7 point Likert Scale $(1=$ Disagree Very Strongly, 2 = Disagree Strongly, $3=$ Disagree, $4=$ Neutral, 5 = Agree, 6 $=$ Agree Strongly, 7 = Agree Very Strongly). Some of the items in the questionnaire are 
negatively phrased and so are scored in reverse during the analysis. This is to improve the reliability of the multi-item factors. The questionnaire was administered by teachers to their pupils at start and end of the projects in school.

The questionnaire was piloted before its use by teachers in schools. The respondents to the pilot reacted negatively to the ordering of the items in the questionnaire as they were aware of the multiple items trying to assess the same factor. To address this, the questionnaire items were randomised.

\section{Analysis}

A factor analysis of the questionnaire responses was calculated first to verify if the 18 items in the questionnaire were measuring the 3 expected factors of the IMI that were selected (Tabachnick \& Fidell, 2001). Factor analysis was used to investigate if there was structure in the pattern of correlations between variables, this analysis expects to determine if the 18 items measured actually represent the 3 subscales of Interest/Enjoyment, Perceived Competence and Pressure/Tension (Brace, Kemp, \& Snelgar, 2012).

Before conducting the factor analysis two calculations were used to determine the suitability of the data for factor analysis. The Kaiser-Meyer-Olkin Measure of sampling Adequacy is used to test the amount of variance within the data that could be explained by factors, values above 0.6 are considered acceptable. Bartlett's test of sphericity tests that the data is factorable if significant. Passing these two tests suggests suitability of the data for factor analysis (Brace et al., 2012).

There are two common methods of Factor Analysis, Exploratory Factor Analysis (EFA) and Principal Components Analysis (PCA) (Brown, 2009c; Tabachnick \& Fidell, 2001). Exploratory Factor Analysis (EFA) methods were best suited to the items in this study; as the items in the questionnaires were developed on theory from previous 
research (Brown, 2009b). To achieve optimal results Costello \& Osborne (2005) recommend the use of the maximum likelihood EFA method, that was available within the software IBM SPSS Statistics 22 used for this analysis.

To make the pattern of loadings for each factor clearer, rotation methods are required to analyse EFA data; oblique and orthogonal rotation methods maximise high correlations and minimise low ones. The oblique Oblimin with Kaiser Normalization rotation method was selected as there is expected correlation between factors (Tabachnick \& Fidell, 2001). Oblique rotation is also favourable as it can reproduce orthogonal solutions (Costello \& Osborne, 2005).

A priori criteria were used to extract 3 factors, this is based on the number of expected factors found in previous research using this instrument (Brown, 2009a). Only factors with a loading greater than 0.32 are interpreted as this is the threshold for $10 \%$ overlapping variance (Tabachnick \& Fidell, 2001). The structure matrix has been used to interpret factor loading as it accounts for correlations between factors (Brace et al., 2012), the alternative pattern matrix may appear to show no loading as it only shows unique variance once overlap of correlations are omitted (Tabachnick \& Fidell, 2001).

Following the EFA the reliability of each identified factor was tested for internal consistency using the calculations for Cronbach’s alpha coefficients. Cronbach’s alpha was calculated for each factor with values greater than 0.7 being accepted (Brace et al., 2012; Gliem \& Gliem, 2003).

If the factor passed the tests for reliability then, following the instructions for using the IMI, the factor scores are calculated as the mean score for all the items in that factor. These factor scores have been used in the analysis of results. Box plots and nonparametric central tendency statistics were calculated to present the start and end results of the factors. The box plot displays median, interquartile range and range statistics for 
data. The features of a box plot are shown in Figure 1. Box plots were selected as the most appropriate method, compared to histograms or tables, for the display of these statistical calculations. The box plots provide clear comparison of statistics between the factors calculated by observation of the movement of the box.

\section{[Figure 1]}

To determine if there were statistically significant differences in the data collected before and after the nonparametric Wilcoxon Signed Ranks test was used. The Wilcoxon test is the nonparametric equivalent of the paired t-test (Brace et al., 2012). Wilcoxon Signed Rank Tests were used to compare the start and end of project results for each factor and assess if there were any statistically significant differences in results (Brace et al., 2012). These test statistics were calculated for the entire data set to observe changes across the whole available sample. They were also calculated for each individual school within the study, as sample sizes for individual school were small, exact test statistics were used to ensure that the data meets the assumptions of the tests (Mehta \& Patel, 2013). The effect size, $r$, was manually calculated for the test of significance (Pallant, 2007, p. 225). IBM SPSS Statistics 22 was used to perform all other calculations in this analysis.

\section{Results}

\section{Participants}

The number of questionnaire responses and the amount of missing data from the responses are shown in Table 1. A total of 959 participated in some part of the questionnaire process, from 31 schools. 860 pupils returned the start of project questionnaire, 117 of the start of project questionnaires were rejected due to missing data or errors made on the questionnaire resulting in a total of 743 complete responses. 
699 pupils returned the end of project questionnaire, 101 of the end of project questionnaires were rejected due to missing data or errors made on the questionnaire resulting in a total of 598 complete responses. 652 pupils returned both the start and end of project questionnaire, 194 participants results were rejected due to missing data or errors made on the questionnaire resulting in a total of 458 complete responses.

[Table 1]

With the amount of missing data for participants who completed the before and after questionnaires at $29.75 \%$ data imputation methods were considered unsuitable (Gelman \& Hill, 2006; Scheffer, 2002). Cases with missing data values have been excluded test-by-test to preserve the maximum amount of useable data. The size of the sample used in each calculation is provided in these results.

The sample size of 458 provides a confidence interval of $4.58 \%$ at $95 \%$ confidence level (Krejcie \& Morgan, 1970) from a population figure of 483,795 state funded secondary school pupils (Department for Education, 2015). Therefore, the sample can be considered valid and the data for complete cases has been used.

The total number of unique pupils that participated in the study were 959. The gender distribution shown was 234 males, 419 females and 306 with no answer given. The distribution of gender was skewed towards a high percentage of female pupils responding. Of the 31 responding schools, 3 were all girls and 1 was all boys.

\section{Factor Analysis}

Two factor analyses were calculated for the 18 items in each of the Start and End of project pupil questionnaires. Initially the factorability of the 18 items in each questionnaire was examined. For the start of project questionnaire, the Kaiser-MeyerOlkin Measure of sampling Adequacy was 0.922, above the recommended value of 0.6, and Bartlett's test of sphericity was significant $\left(\chi^{2}(153)=6773.252, p<.01\right)$. For the 
end of project questionnaire, the Kaiser-Meyer-Olkin Measure of sampling Adequacy was 0.932 , above the recommended value of 0.6 , and Bartlett's test of sphericity was significant $\left(\chi^{2}(153)=6621.758, p<.01\right)$. Given these indicators, factor analysis was conducted on all 18 items in both questionnaires.

EFA was conducted using the maximum likelihood method with oblique rotation using the Oblimin with Kaiser Normalization rotation method. Three factors were extracted for each of the 18 items in the two questionnaires. Values for the start of project pupil questionnaire showed that factor 1 explained $37.9 \%$ of the variance, factor 2 explained $8.3 \%$ of the variance and factor 3 explained $6.0 \%$ of the variance. The 3 factor solution for the start of project questionnaire explained $52.1 \%$ of the total variance. Values for the end of project pupil questionnaire showed that factor 1 explained $43.7 \%$ of the variance, factor 2 explained $8.9 \%$ of the variance and factor 3 explained $4.9 \%$ of the variance. The 3 factor solution for the end of project questionnaire explained $57.5 \%$ of the total variance.

The loading of factors for the start and end questionnaires are shown in Table 2. The items have been organised by their highest factor loading. The highest loading of each item is shown in bold type. The items and factors calculated in this EFA match the intended design of the questionnaire. As planned the loading of items to factors is the same in the start and end questionnaires. Questions 1, 3, 6, 8, 14, 15 and 18 load onto factor 1 Interest/Enjoyment, questions 2, 12, 13, 16 and 17 load onto factor 2 Pressure/Tension and questions 4, 5, 7, 9, 10 and 11 load onto factor 3 Perceived Competence.

The factor pressure/tension would be expected to have an inverse relationship to perceived competence. The structure matrix used has revealed the high levels of expected correlation between factors. This negative correlation is demonstrated in the 
significant negative loading on Items 11, 12 and 13. The items are sensitive to order and this could explain lower levels of primary loading for items 11 and 13 compared to previous experiments.

[Table 2]

\section{Validity Test}

Internal consistency for each of the factors was examined using Cronbach’s alpha. For the start of project pupil questionnaire the Interest/Enjoyment factor consisted of 7 items ( $\mathrm{n}=785, \alpha=.887)$, the Pressure/Tension factor consisted of 5 items ( $\mathrm{n}=787, \alpha=$ .773), the Perceived Competence factor consisted of 6 items $(n=827, \alpha=.824)$. For the end of project pupil questionnaire the Interest/Enjoyment factor consisted of 7 items (n $=636, \alpha=.905)$, the Pressure/Tension factor consisted of 5 items $(n=648, \alpha=.800)$, the Perceived Competence factor consisted of 6 items $(n=652, \alpha=.865)$. All calculated alphas were above the recommended 0.7 threshold for acceptance.

\section{Descriptive Statistics}

For each pupil’s complete questionnaire, the 3 factor scores were calculated. Central tendency statistics were calculated for the three factors in the start and end of project questionnaires, these are presented in Table 3.

[Table 3]

The calculated scores for all the factors are presented as box plots for descriptive analysis, see Figure 2. There were more responses to the start of project questionnaire (n $=743)$ compared to the end of project questionnaire $(n=598)$. The score is based on a 7 point Likert scale, scores greater than 4 are positive responses from pupils; scores less than 4 are negative responses. 
The central tendency statistics and box plot show the high starting position for Interest/Enjoyment and Perceived Competence and the low starting position of Pressure/Tension. Higher scores are desirable for Interest/Enjoyment and Perceived Competence, while low scores are desirable for Pressure/Tension.

The results in Table 3 and Figure 2 show no change in the median scores for Interest/Enjoyment between the start and end of the project. There is an increase in median Perceived Competence scores between start and end of the project and a decrease in median Pressure/Tension scores.

[Figure 2]

Central tendency statistics were also calculated for the starting scores for male and female participants, Figure 3. The figure shows that female participants responded with lower median factors scores in Interest/Enjoyment and in Perceived Competence than the male pupils. The female participants also scored higher in Pressure/Tension than the male pupils. The female pupils have scored themselves as being less motivated and less able in technology education, but they are also less pressured than the male pupils.

\section{Changes to pupil scores}

The first calculated differences in pupils scores between the start and end of the project were made on all available data to report impact for the entire study.

No significant difference between start $(\mathrm{n}=743, \mathrm{Mdn}=4.9, \mathrm{IQR}=1.5)$ and end $(\mathrm{n}$ $=598, \mathrm{Mdn}=4.9, \mathrm{IQR}=1.5$ ) of project Interest/Enjoyment scores was found using a Wilcoxon Signed Ranks Test of Asymp. Sig. (2-tailed) $(\mathrm{n}=458, \mathrm{Z}=-1.427, p=.154, r$ $=0.05)$. There was no significant change in the whole study scores of pupil Interest/Enjoyment. However, the median starting score was that pupils were already positively motivated in technology. 
A significant difference between start $(\mathrm{n}=743, \mathrm{Mdn}=4.7, \mathrm{IQR}=1.0)$ and end $(\mathrm{n}=598, \mathrm{Mdn}=4.8, \mathrm{IQR}=1.2)$ of project Perceived Competence scores was found using a Wilcoxon Signed Ranks Test of Asymp. Sig. (2-tailed) $(n=458, Z=-3.994, p<$ $.001, r=0.13)$. There was a significant increase in the whole study scores of pupil Perceived Competence.

A significant difference between start $(\mathrm{n}=743, \mathrm{Mdn}=3.2, \mathrm{IQR}=1.6)$ and end $(\mathrm{n}=598, \mathrm{Mdn}=4.8, \mathrm{IQR}=1.3)$ of project Pressure/Tension scores was found using a Wilcoxon Signed Ranks Test of Asymp. Sig. (2-tailed) ( $\mathrm{n}=458, \mathrm{Z}=-4.278, p<.001, r$ $=0.14)$. There was a significant decrease in the whole study scores of pupil Pressure/Tension.

The calculations of factor scores for each gender are presented in Table 4 . The demographic of pupil participants in the study was skewed towards more female pupils (234 males, 419 females and 306 with no answer given). Comparisons were made between the factor scores between male and female pupils. The descriptive statistics of the start of project pupil questionnaire show that females are in a less motivated and confident starting position compared to male pupils. However, there was no significant difference between the aggregate factors scores and the factor scores of male and female pupils.

[Table 4]

The size effect of the statistical calculations above were small $(r<.3)$ and required further analysis. This was achieved through the calculation of Wilcoxon Signed Ranks Test statistics for each individual school. This identified changes to the factor scores in more detail and described the impact of the project in each school. Exact significance tests were calculated as the sample size from individual schools is small. The calculations for each school's pupil change in factor scores are shown in 
Table 5. The statistically significant results are marked with the direction of change. In 5 schools, 0 pupils returned both the start and end of project questionnaires, and therefore no change in project score statistics could be calculated for these schools.

This more detailed analysis shows that actually only 6 of the 31 schools had a statistically significantly positive improvement in pupil Interest/Enjoyment, see the items marked $a$ in Table 5 for Schools 2, 5, 10, 20, 25 and 26. The factors of Interest/Enjoyment and Perceived Competence that have statistically significant changes feature mostly positive improvements and the Pressure/Tension factor are mostly negative, as would be expected from a successful intervention in schools.

The unexpected significant results are with schools 4, 14 and 27. These schools have inverse significant changes which would suggest reductions in pupil of Interest/Enjoyment and Perceived Competence and increases in Pressure/Tension as a result of the intervention.

[Table 5]

\section{Discussion}

Both the female and male pupils rated themselves as positively motivated towards technology education at the start of the project. However, the starting position for males was less pressured. Technology is traditionally perceived in schools as a more masculine subject (Colley, Comber, \& Hargreaves, 1994) and although the difference in technology subject preference is decreasing it is still favoured by boys (Colley \& Comber, 2003; Hasni \& Potvin, 2015).

This suggests that pupils are interested at some level in technology education. The project was however, unable to make improvements to pupil motivation in the subject. There was no significant change in pupil motivation between the start and end of project questionnaires. The skewed sample does not introduce bias towards the 
changes in pupil factor scores between the start and end of the project. The analysis showed no difference in the change of pupil scores for males and females. These results are aligned to other research studying global science and technology educational results (Potvin \& Hasni, 2014). Other research has reported a decrease in pupils’ sciencerelated interests and attitudes in the primary to secondary school transition (Christidou, 2011) and that pupils attitudes towards 'practical work in science' was unchanged (Barmby, Kind, \& Jones, 2008).

Pupils reported that learning did take place as there was a significant improvement in pupils’ perceived competence scores. However, these improvements did not result in changes to interest/enjoyment scores. This project was intended to provide new resources to help teachers achieve an improvement in motivation. Therefore, the inability to improve pupil motivation in the subject is a key finding. The increased competency scores may have an impact on pupil motivation if pupils had enough time to continue to develop their knowledge.

The reasons for no change in pupil motivation were not captured within the study but they may be explained by the quality of the schemes of work or by teachers' own motivation. Intrinsic motivation requires autonomy (Hill, 2007). Pupils might not be more motivated by these projects as they were tasks that did not promote autonomy. There is a connection between teacher motivation and pupil motivation (Atkinson, 2000). Teaching technology with an appropriate context should help motivate pupils (Dreyfus \& Dreyfus, 1980; McCormick, 2004; Ofsted, 2011a, 2012; Pryde, 2007; Ritz, 2011). As the resources were small stand-alone projects they may not have enough autonomy or depth to engage pupils.

\section{Conclusion}

Contributions have been made to the understanding of pupils who are in receipt of the 
technology teaching. This research measured the level of motivation of pupils. The findings were that in KS3, pupils are motivated in studying technology education, with a higher initial motivation scores for boys compared to girls, see Figure 3. Each pupil cohort was delivered one of a range of short technological projects during their D\&T lessons which were intended to improve technology learning and motivation. These projects were not able to improve the motivation level of pupils as there was no statistically significant change to the pupil motivation measurements taken at the start and end of the study $(\mathrm{n}=458, \mathrm{Z}=-1.427, p=.154, r=0.05)$. There were measured, statistically significant, improvements in pupils perceived competence during the project ( $\mathrm{n}=458, \mathrm{Z}=-3.994, p<.001, r=0.13$ ) suggesting that pupils did understand more.

Although the pupils' starting position was positively motivated the aim was to increase current level to grow the number of school leavers selecting engineering and technology higher education and career paths. If pupils’ motivation towards technology is not being improved by the subject this could be used to explain the reduction in the number of pupils studying technology beyond compulsory education, and subsequently the difficulties experienced by industry in recruiting engineers and technologists. The unimproved motivation factor measured also highlights a disparity between subject experts and teachers' opinions of which lessons and resources can impact pupils and what pupils are motivated to study. The results suggest that this type of intervention, providing projects and resources to schools, is not sufficient without providing further education and time for teachers to develop effective schemes of work.

\section{Acknowledgements}

The authors would like to thank Andy Mitchell and Emma Watson from the Design and Technology Association for their management of the 'Enhancing the teaching of STEM through 
Design and Technology (Mindsets STEM Enhancement Project)’ and their significant contribution to the project.

\section{Disclosure statement}

No potential conflict of interest was reported by the authors.

\section{Funding Information}

This work was supported by the London Schools Excellence Fund (Reference: LSEFR1210) and The Design and Technology Association.

\section{Notes on contributors}

Lewis Jones is an early career lecturer in the Optical Engineering Research Group at Loughborough University. His research interests include laser manufacturing processes and how they influence engineering design. His $\mathrm{PhD}$ research work was focused on the engineering subject knowledge training needs of teachers working with manufacturing technology.

Hilary McDermott is a Senior Lecturer in Psychology within the School of Sport, Exercise and Health Sciences at Loughborough University. Her research expertise concerns health and wellbeing with a strong emphasis on injury prevention, particularly within the context of work. She has expertise in qualitative research design and analysis and has drawn on this to inform her teaching of this topic. She is a Fellow of the Higher Education Academy.

John Tyrer is the Professor of Optical Instrumentation. He has 4 primary research interests; Optical Measurement/Detection, Holography, High Power Laser Processing and Laser Safety. He teaches Engineering Component Design, High Power Laser Processing, Laser Safety, Optical Engineering and Ballistics \& Rocketry. He is heavily involved in outreach activities with regular talks on a wide range of Engineering Applications. He established a university Spin-Out company - Laser Optical Engineering Ltd in May 1996. As Managing Director \& founder, John now employs 6 permanent members of staff. John was awarded Fellow status by the IMechE and The Laser Institute of America.

Nigel Zanker is an Honorary Fellow of Loughborough Design School where he is a Learning and Teaching Advisor and MSc Design Education Programme Director. His research and publications are concerned with evaluation of pedagogic practice in design/technology education. 


\section{ORCID}

Lewis Jones http://orcid.org/0000-0002-6413-4599

\section{References}

Alexander, C, D Tillman, J D Cohen, G J Ducamp, and W Kjellstrom. 2013. "Piloting Innovative Learning Experiences: Measuring Outcomes of Digital Fabrication Activities across Five Classes.” In Proceedings of Society for Information Technology \& Teacher Education International Conference 2013, 1165-73.

Atkins. 2015. "Skills Deficit.”

Atkinson, Stephanie. 2000. “An Investigation into the Relationship Between Teacher Motivation and Pupil Motivation.” Educational Psychology 20 (1): 45-57. doi:10.1080/014434100110371.

Barlex, D, and Marion Rutland. 2008. “DEPTH2: Design \& Technology Trainee Teacher's Use of a Subject Construct Model to Enable Reflective Critique of School Experience.” International Journal of Technology and Design Education 18 (3): 231-46. doi:10.1007/s10798-008-9054-8.

Barmby, Patrick, Per M. Kind, and Karen Jones. 2008. “Examining Changing Attitudes in Secondary School Science.” International Journal of Science Education 30 (8): 1075-93. doi:10.1080/09500690701344966.

Beyers, Ronald Noel. 2010. "Nurturing Creativity and Innovation Through FabKids: A Case Study.” Journal of Science Education and Technology 19 (5): 447-55. doi:10.1007/s10956-010-9212-0.

Botcherby, Sue, and Lisa Buckner. 2012. “Women in Science, Technology, Engineering and Mathematics: From Classroom to Boardroom.” Bradford.

Brace, Nicola, Richard Kemp, and Rosemary Snelgar. 2012. SPSS for Psychologists. 5th ed. Basingstoke, Hampshire: Palgrave Macmillan.

Brown, James Dean. 2009a. "Statistics Corner Questions and Answers about Language Testing Statistics: Choosing the Right Number of Components or Factors in PCA and EFA.” Shiken: JALT Testing \& Evaluation SIG Newsletter 13 (2): 1923.

2009b. "Statistics Corner Questions and Answers about Language Testing Statistics: Choosing the Right Type of Rotation in PCA and EFA.” Shiken: JALT Testing \& Evaluation SIG Newsletter 13 (3): 20-25. 
_ 2009c. "Statistics Corner Questions and Answers about Language Testing Statistics: Principal Components Analysis and Exploratory Factor Analysis Definitions, Differences and Choices.” Shiken: JALT Testing \& Evaluation SIG Newsletter 13 (1): 26-30.

Bull, Glen, and Joe Garofalo. 2009. "Personal Fabrication Systems: From Bits to Atoms.” Learning \& Leading with Technology 36 (7). International Society for Technology in Education. 180 West 8th Avenue, Suite 300, Eugene, OR 974012916. Tel: 800-336-5191; Tel: 541-302-3777; Fax: 541-302-3778; e-mail: iste@iste.org; Web site: http://www.iste.org: 10-12.

Bybee, Rodger W. 2010. “What Is STEM Education?” Science 329 (5995): 996. doi:10.1126/science.1194998.

Chin, Christine, and David E. Brown. 2000. “Learning in Science: A Comparison of Deep and Surface Approaches.” Journal of Research in Science Teaching 37 (2): 109-38.

Choulerton, Diana. 2015. "From Here to Where? The Current State of Design and Technology.” Loughborough University.

Christidou, Vasilia. 2011. "Interest, Attitudes and Images Related to Science :

Combining Students' Voices with the Voices of School Science, Teachers, and Popular Science.” International Journal of Environmental Science Education 6 (2): 141-59.

Colley, Ann, and Chris Comber. 2003. "School Subject Preferences: Age and Gender Differences Revisited.” Educational Studies 29 (1): 59-67. doi:10.1080/03055690303269.

Colley, Ann, Chris Comber, and David J. Hargreaves. 1994. "School Subject Preferences of Pupils in Single Sex and Co-Educational Secondary Schools.” Educational Studies 20 (3): 379-85. doi:10.1080/0305569940200306.

Cordova, Diana I., and Mark R. Lepper. 1996. "Intrinsic Motivation and the Process of Learning: Beneficial Effects of Contextualization, Personalization, and Choice.” Journal of Educational Psychology 88 (4): 715-30. doi:10.1037/00220663.88.4.715.

Costello, Anna B, and Jason W Osborne. 2005. "Best Practices in Exploratory Factor Analysis: Four Recommendations for Getting the Most From Your Analysis.” Practical Assessment, Research \& Evaluation 10 (7): 1-9. 
Cox, Tony. 2007. "Electronics.” In Analyzing Best Practices in Technology Education, edited by Marc de Vries, Rod Cluster, John R. Dakers, and Gene Martin, 59-67. Rotterdam: Sense Publishers.

Deci, Edward L., H Eghrari, B. C Patrick, and D. R Leone. 1994. "Facilitating Internalization: The Self-Determination Theory Perspective.” Journal of Personality 62 (1): 199-142. doi:10.1111/j.1467-6494.1994.tb00797.x.

Deci, Edward L., and Richard M. Ryan. 1985. Intrinsic Motivation and SelfDetermination in Human Behavior. New York: Plenum.

_ 2000. “The 'What' and 'Why' of Goal Pursuits: Human Needs and the SelfDetermination of Behavior.” Psychological Inquiry 11 (4): 227-68. doi:10.1207/S15327965PLI1104_01.

Department for Education. 2013. "Design and Technology Programmes of Study : Key Stage 3 National Curriculum in England.”

—. 2015. "Schools, Pupils and Their Characteristics: January 2015.”

Dreyfus, Stuart E., and Hubert L. Dreyfus. 1980. “A Five-Stage Model of the Mental Activities Involved in Directed Skill Acquisition (No. ORC-80-2).” Operations Research Center.

Eisenberg, M, A Eisenberg, S Hendrix, G Blauvelt, D Butter, J Garcia, R Lewis, and T Nielsen. 2003. “As We May Print: New Directions in Output Devices and Computational Crafts for Children.” In Proceedings of the 2003 Conference on Interaction Design and Children, 31-39. ACM.

Gelman, Andrew, and Jennifer Hill. 2006. “Missing-Data Imputation.” In Data Analysis Using Regression and Multilevel/Hierarchical Models, 529-44. Cambridge: Cambridge University Press. doi:10.1017/CBO9780511790942.031.

Gillet, Nicolas, Robert J. Vallerand, and Marc André K Lafrenière. 2012. "Intrinsic and Extrinsic School Motivation as a Function of Age: The Mediating Role of Autonomy Support.” Social Psychology of Education 15: 77-95. doi:10.1007/s11218-011-9170-2.

Gliem, Joseph A, and Rosemary R Gliem. 2003. “Calculating, Interpreting, and Reporting Cronbach’s Alpha Reliability Coefficient for Likert-Type Scales,.” 2003 Midwest Research to Practice Conference in Adult, Continuing, and Community Education, no. 1992: 82-88. doi:10.1109/PROC.1975.9792.

Harrison, Matthew. 2012. "Jobs and Growth: The Importance of Engineering Skills to the UK Economy.” London. 
Hasni, Abdelkrim, and Patrice Potvin. 2015. "Student’s Interest in Science and Technology and Its Relationships with Teaching Methods, Family Context and Self-Efficacy.” International Journal of Environmental \& Science Education 10 (3): 337-66. doi:10.12973/ijese.2015.249a.

HESA. 2014. "Students, Qualifiers and Staff Data Tables.” https://www.hesa.ac.uk/content/view/1973/239/.

Hill, Ann Marie. 2007. “Motivational Aspects.” In Analyzing Best Practices in Technology Education, edited by Marc de Vries, Rod Cluster, John R. Dakers, and Gene Martin, 203-11. Rotterdam: Sense Publishers.

IMechE. 2011. "Meeting the Challenge: Demand and Supply of Engineers in the UK.” JCQ CIC. 2014. “A-Levels - JCQ Joint Council for Qualifications.” http://www.jcq.org.uk/examination-results/a-levels.

Jones, Lewis C R. 2016. “An Investigation into the Knowledge and Skill Requirements for Effective Teaching of Technology in English Secondary Schools.” Loughborough University.

Jones, Lewis C R, John R Tyrer, and Nigel Zanker. 2013. “Applying Laser Cutting Techniques through Horology for Teaching Effective STEM in Design and Technology.” Design and Technology Education: An International Journal 18 (3): 21-34.

Kimbell, Richard. 1994. "Progression in Learning and the Assessment of Children's Attainments in Technology.” International Journal of Technology and Design 4 (1): 65-83. doi:10.1007/BF01197584.

Krejcie, Robert V, and Daryle W Morgan. 1970. “Determining Sample Size for Research Activities.” Education and Psychological Measurement 30 (3): 60710. doi:10.1177/001316447003000308.

Kusurkar, R. a., Th J. Ten Cate, C. M P Vos, P. Westers, and G. Croiset. 2013. "How Motivation Affects Academic Performance: A Structural Equation Modelling Analysis.” Advances in Health Sciences Education 18: 57-69. doi:10.1007/s10459-012-9354-3.

Lamberty, K K. 2008. “Creating Mathematical Artifacts.” In Proceedings of the 7th International Conference on Interaction Design and Children - IDC '08, 226. New York, New York, USA: ACM Press. doi:10.1145/1463689.1463760. Lewis, Tim, Nick Baldwin, Jenny Dein, and P Grover. 2005. “The Technology Enhancement Programme (TEP) Millennium Research - a Positive Intervention 
to Change the D\&T Curriculum.” In DATA International Research Conference, 115-24.

Lin, Yi-Guang, Wilbert J McKeachie, and Yung Che Kim. 2003. “College Student Intrinsic And/or Extrinsic Motivation and Learning.” Learning and Individual Differences 13 (January): 251-58. doi:10.1016/S1041-6080(02)00092-4.

Loukomies, Anni, Dimitris Pnevmatikos, Jari Lavonen, Anna Spyrtou, Reijo Byman, Petros Kariotoglou, and Kalle Juuti. 2013. “Promoting Students’ Interest and Motivation Towards Science Learning: The Role of Personal Needs and Motivation Orientations.” Research in Science Education 43 (6): 2517-39. doi:10.1007/s11165-013-9370-1.

Marton, F., and R. Säljö. 2005. “Approaches to Learning.” In The Experience of Learning: Implications for Teaching and Studying in Hgher Education., edited by F. Marton, D. Hounsell, and N. Entwistle, 3rd (inter, 39-58. Edinburgh: University of Edinburgh, Centre for Teaching, Learning and Assessment. Matthews, David. 2014. “Subject to Popular Demand.” Times Higher Education. McCormick, Robert. 2004. "Issues of Learning and Knowledge in Technology Education.” International Journal of Technology and Design Education 14 (1): $21-44$.

Mehta, Cyrus R, and Nitin R Patel. 2013. "IBM SPSS Exact Tests.”

Musta’amal, A. H., Eddie Norman, and Tony Hodgson. 2009. “Gathering Empirical

Evidence Concerning Links Between Computer Aided Design ( CAD ) and Creativity.” Design and Technology ... 14 (2): 53-66.

Ofsted. 2008. "Education for a Technologically Advanced Nation. Design and Technology in Schools 2004-07 (070224).” London.

. 2011a. "Computer-Aided Design and Manufacture in Design and Technology:

Ripley St Thomas Church of England High School.”

_ 2011b. "Meeting Technological Challenges? Design and Technology in Schools 2007-10 (100121).”

—. 2012. "High Quality Innovation in Key Stage 3 Design and Technology to Promote High Achievement: Archbishop Holgate’ S School - A Church of England Academy.”

Pallant, Julie. 2007. SPSS Survival Manual. McGraw-Hill Education.

Plant, Robert W., and Richard M. Ryan. 1985. "Intrinsic Motivation and the Effects of Self-Consciousness, Self-Awareness, and Ego-Involvement: An Investigation of 
Internally Controlling Styles.” Journal of Personality 53 (3): 435-49. doi:10.1111/j.1467-6494.1985.tb00375.x.

Potvin, Patrice, and Abdelkrim Hasni. 2014. "Interest, Motivation and Attitude towards Science and Technology at K-12 Levels: A Systematic Review of 12 Years of Educational Research.” Studies in Science Education 50 (1): 85-129. doi:10.1080/03057267.2014.881626.

Pryde, Kenneth. 2007. “Probing Our Technological Past.” In Analyzing Best Practices in Technology Education, edited by Marc de Vries, Rod Cluster, John R. Dakers, and Gene Martin, 45-58. Rotterdam: Sense Publishers.

Ritz, John M. 2011. “Using Contextualized Engineering and Technology Education to Increase Student Motivation in the Core Academics.” In Fostering Human Development Through Engineering and Technology Education, edited by Moshe Barak and Michael Hacker, 131-51. Rotterdam: Sense Publishers.

Roberts, Gareth. 2002. "SET for Success The Supply of People with Science, Technology, Engineering and Mathematics Skills.”

Ryan, Richard M. 1982. "Control and Information in the Intrapersonal Sphere: An Extension of Cognitive Evaluation Theory.” Journal of Personality and Social Psychology 43 (3): 450-61.

Ryan, Richard M., James P. Connell, and Robert W. Plant. 1990. "Emotions in Nondirected Text Learning.” Learning and Individual Differences 2 (1): 1-17. doi:10.1016/1041-6080(90)90014-8.

Ryan, Richard M., and Edward L. Deci. 2000a. "Self-Determination Theory and the Facilitation of Intrinsic Motivation, Social Development, and Well-Being.” American Psychologist 55 (1): 68-78. doi:10.1037/0003-066X.55.1.68.

- 2000b. "Intrinsic and Extrinsic Motivations: Classic Definitions and New Directions.” Contemporary Educational Psychology 25 (1): 54-67. doi:10.1006/ceps.1999.1020.

Ryan, Richard M., Riachard Koestner, and Edward L. Deci. 1991. "Ego-Involved Persistence: When Free-Choice Is Not Instrinsically Motivated.” Motivation and Emotion 15 (3): 185-204.

Scheffer, Judi. 2002. “Dealing with Missing Data.” Res. Lett. Inf. Math. Sci. 3: 153-60. doi:10.1159/000100481. 
Smith, Emma. 2011. "Women into Science and Engineering? Gendered Participation in Higher Education STEM Subjects.” British Educational Research Journal 37 (6): 993-1014. doi:10.1080/01411926.2010.515019.

Sproule, J., R. Martindale, J. Wang, P. Allison, C. Nash, and S. Gray. 2013.

"Investigating the Experience of Outdoor and Axdventurous Project Work in an Educational Setting Using a Self-Determination Framework.” European Physical Education Review 19 (3): 315-28. doi:10.1177/1356336X13495629.

Tabachnick, Barbara. G., and Linda. S. Fidell. 2001. Using Multivariate Statistics. Needham Heights, MA: Allyn \& Bacon.

Uyulgan, Melis Arzu, and Nalan Akkuzu. 2014. “An Overview of Student Teachers’ Academic Intrinsic Motivation.” Educational Sciences: Theory \& Practice 14 (1): 24-32. doi:10.12738/estp.2014.1.2013.

Vaino, Katrin, Jack Holbrook, and Miia Rannikmäe. 2012. “Stimulating Students' Intrinsic Motivation for Learning Chemistry through the Use of Context-Based Learning Modules.” Chemistry Education Research and Practice 13 (4): 41019. doi:10.1039/c2rp20045g.

Warburton, Kevin. 2003. "Deep Learning and Education for Sustainability.” International Journal of Sustainability in Higher Education 4 (1): 44-56. doi:10.1108/14676370310455332.

Zanker, Nigel. 2005. "Is the Steady Hand Game an Appropriate Project for This Decade? An Analysis of the Factors Why Teacher Trainees in an ITT Partnership Are Not Moving Projects Forward.” In DATA International Research Conference, 181-90. 
Table 1. Number of questionnaire responses and missing data for the pupil questionnaire

\begin{tabular}{llll}
\hline & $\begin{array}{l}\text { Number of } \\
\text { responses }\end{array}$ & $\begin{array}{l}\text { Number of Complete } \\
\text { Responses }\end{array}$ & $\begin{array}{l}\text { Missing } \\
\text { Data }\end{array}$ \\
\hline $\begin{array}{l}\text { Start of project pupil questionnaire } \\
\text { End of project pupil Questionnaire }\end{array}$ & 860 & 743 & $13.60 \%$ \\
\hline $\begin{array}{l}\text { Both the start and end of project pupil } \\
\text { questionnaires }\end{array}$ & 699 & 598 & $14.45 \%$ \\
\hline
\end{tabular}

Total unique pupils $(\mathrm{n}=959)$, Total unique schools $(\mathrm{n}=31)$ 
Table 2. Structure matrix of factor loadings based on EFA using maximum likelihood and oblimin rotation for 18 items in the start of project pupil questionnaire $(n=743)$

\begin{tabular}{|c|c|c|c|c|c|c|c|}
\hline \multirow{3}{*}{$\begin{array}{l}\text { Start } \\
\text { Question }\end{array}$} & \multicolumn{3}{|c|}{$\begin{array}{l}\text { Factor loadings in the start of project } \\
\text { pupil questionnaire }(n=743)\end{array}$} & \multirow{3}{*}{$\begin{array}{l}\text { End } \\
\text { Question }\end{array}$} & \multicolumn{3}{|c|}{$\begin{array}{l}\text { Factor loadings in the end of project } \\
\text { pupil questionnaire }(n=597)\end{array}$} \\
\hline & (1) & (2) & (3) Perceived & & (1) & (2) & (3) Perceived \\
\hline & $\begin{array}{l}\text { Interest/ } \\
\text { Enjoyment }\end{array}$ & $\begin{array}{l}\text { Pressure/ } \\
\text { Tension }\end{array}$ & Competence & & $\begin{array}{l}\text { Interest/ } \\
\text { Enjoyment }\end{array}$ & $\begin{array}{l}\text { Pressure/ } \\
\text { Tension }\end{array}$ & Competence \\
\hline SQ1 & .669 & -.380 & .338 & EQ1 & .715 & -.359 & .424 \\
\hline SQ3 & .758 & & .454 & EQ3 & .811 & & .568 \\
\hline SQ6 & .487 & -.409 & & EQ6 & .602 & -.396 & \\
\hline SQ8 & .838 & & .633 & EQ8 & .879 & & .646 \\
\hline SQ14 & .841 & & .538 & EQ14 & .823 & & .583 \\
\hline SQ15 & .884 & & .582 & EQ15 & .862 & & .545 \\
\hline SQ18 & .630 & & .409 & EQ18 & .676 & & .461 \\
\hline SQ2 & -.402 & .571 & & EQ2 & -.402 & .555 & -.388 \\
\hline SQ12 & & .356 & -.418 & EQ12 & & .447 & -.473 \\
\hline SQ13 & -.480 & .547 & -.627 & EQ13 & -.502 & .562 & -.608 \\
\hline SQ16 & & .803 & & EQ16 & & .809 & -.390 \\
\hline SQ17 & & .801 & -.322 & EQ17 & & .842 & -.360 \\
\hline SQ4 & .435 & & .783 & EQ4 & .533 & -.363 & .806 \\
\hline SQ5 & .394 & & .744 & EQ5 & .442 & -.322 & .735 \\
\hline SQ7 & .482 & & .624 & EQ7 & .580 & -.388 & .679 \\
\hline SQ9 & .551 & & .707 & EQ9 & .601 & -.411 & .838 \\
\hline SQ10 & .525 & & .785 & EQ10 & .601 & -.403 & .845 \\
\hline SQ11 & & -.415 & .360 & EQ11 & .375 & -.519 & .430 \\
\hline
\end{tabular}

Note: Factors loading $<.32$ are suppressed. 
Table 3. Central tendency statistics for pupil questionnaire factor scores

\begin{tabular}{|c|c|c|c|c|}
\hline & \multicolumn{2}{|c|}{ Start $(n=743)$} & \multicolumn{2}{|c|}{ End $(\mathrm{n}=598)$} \\
\hline & Median & IQR & Median & IQR \\
\hline Interest/Enjoyment & 4.9 & 1.5 & 4.9 & 1.5 \\
\hline Perceived Competence & 4.7 & 1.0 & 4.8 & 1.2 \\
\hline Pressure/Tension & 3.2 & 1.6 & 3.0 & 1.3 \\
\hline
\end{tabular}


Table 4. Gender differences for pupil questionnaire scores

\begin{tabular}{|c|c|c|c|c|c|c|}
\hline \multirow[b]{2}{*}{ Factor } & \multicolumn{3}{|c|}{ Male $(n=116)$} & \multicolumn{3}{|c|}{ Female $(\mathrm{n}=232)$} \\
\hline & $\mathrm{Z}$ & $\mathrm{p}$ & $\mathrm{r}$ & $\mathrm{Z}$ & $\mathrm{p}$ & $\mathrm{r}$ \\
\hline Interest/Enjoyment & -0.225 & .822 & 0.01 & -1.297 & .195 & 0.06 \\
\hline Perceived Competence & $-2.332 *$ & .020 & 0.15 & $-2.807 * *$ & .005 & 0.13 \\
\hline Pressure/Tension & $-2.687 * *$ & .007 & 0.18 & $-3.925 * * *$ & .000 & 0.18 \\
\hline
\end{tabular}

Significant at ${ }^{*} p<.05$, two-tailed. ${ }^{* *} p<.01$, two-tailed. ${ }^{* * *} p<.001$, two-tailed. 
Table 5. Changes in pupil scores between start and end of project for each individual school

Wilcoxon Signed Rank Test, $Z(p)$

\begin{tabular}{|c|c|c|c|c|}
\hline \multirow[b]{2}{*}{$\begin{array}{l}\text { Unique } \\
\text { School ID }\end{array}$} & \multirow[b]{2}{*}{$\mathrm{n}$} & \multicolumn{3}{|c|}{ Wilcoxon Signed Rank Test, $Z(p)$} \\
\hline & & Interest/Enjoyment & Perceived Competence & Pressure/Tension \\
\hline 1 & 13 & $-1.494(.073)$ & $-1.833(.033)^{a}$ & $-2.814(.001)^{b}$ \\
\hline 2 & 26 & $-2.152(.015)^{\mathrm{a}}$ & $-2.021(.021)^{\mathrm{a}}$ & $-1.232(.113)$ \\
\hline 3 & 25 & $-.822(.211)$ & $-.229(.414)$ & $-.35(.368)$ \\
\hline 4 & 27 & $-3.52(0)^{b}$ & $-2.605(.004)^{b}$ & $-.217(.418)$ \\
\hline 5 & 20 & $-1.942(.026)^{a}$ & $-1.972(.024)^{\mathrm{a}}$ & $-2.325(.009)^{b}$ \\
\hline 6 & 0 & & & \\
\hline 7 & 12 & $-.846(.215)$ & $-.788(.231)$ & $0(.504)$ \\
\hline 8 & 22 & $-.212(.421)$ & $-.486(.32)$ & $-1.294(.104)$ \\
\hline 9 & 15 & $-.659(.266)$ & $-.699(.255)$ & $-.655(.266)$ \\
\hline 10 & 22 & $-1.795(.037)^{a}$ & $-2.071(.019)^{a}$ & $-.263(.401)$ \\
\hline 11 & 16 & $-.655(.266)$ & $-1.396(.086)$ & $-.211(.427)$ \\
\hline 12 & 19 & $-.085(.472)$ & $-2.696(.002)^{a}$ & $-2.262(.011)^{b}$ \\
\hline 13 & 0 & & & \\
\hline 14 & 21 & $-1.113(.138)$ & $-2.391(.007)^{b}$ & $-3.042(.001)^{\mathrm{a}}$ \\
\hline 15 & 10 & $-1.262(.117)$ & $-.423(.367)$ & $-1.428(.084)$ \\
\hline 16 & 25 & $-.341(.372)$ & $-.564(.292)$ & $-2.268(.011)^{b}$ \\
\hline 17 & 0 & & & \\
\hline 18 & 18 & $-1.156(.134)$ & $-.442(.344)$ & $-.315(.386)$ \\
\hline 19 & 0 & & & \\
\hline 20 & 16 & $-2.182(.013)^{a}$ & $-3.063(0)^{\mathrm{a}}$ & $-2.609(.004)^{b}$ \\
\hline 21 & 0 & & & \\
\hline 22 & 26 & $-1.341(.093)$ & $-1.003(.163)$ & $-.259(.404)$ \\
\hline 23 & 14 & $-.847(.211)$ & $-1.336(.098)$ & $-2.003(.024)^{b}$ \\
\hline 24 & 13 & $-1.016(.166)$ & $-2.536(.004)^{a}$ & $-1.191(.126)$ \\
\hline 25 & 35 & $-3.932(0)^{\mathrm{a}}$ & $-3.325(0)^{\mathrm{a}}$ & $-2.318(.01)^{b}$ \\
\hline 26 & 5 & $-2.032(.031)^{\mathrm{a}}$ & $-2.032(.031)^{\mathrm{a}}$ & $-2.023(.031)^{b}$ \\
\hline 27 & 11 & $-1.188(.133)$ & $-2.001(.022)^{b}$ & $-1.995(.025)^{b}$ \\
\hline 28 & 3 & $-1(.5)$ & $0(.625)$ & $-1.633(.125)$ \\
\hline 29 & 21 & $-1.322(.097)$ & $-1.291(.105)$ & $-.142(.45)$ \\
\hline 30 & 8 & $-.734(.281)$ & $-1.859(.039)^{\mathrm{a}}$ & $-.773(.258)$ \\
\hline 31 & 15 & $-.874(.202)$ & $-.595(.303)$ & $-1.28(.122)$ \\
\hline
\end{tabular}

${ }^{a}$ Significant positive change in scores $(p<.05$, Exact Sig. 1-tailed)

${ }^{\mathrm{b}}$ Significant negative change in scores $(p<.05$, Exact Sig. 1 -tailed) 
Figure 1. Features of a box plot

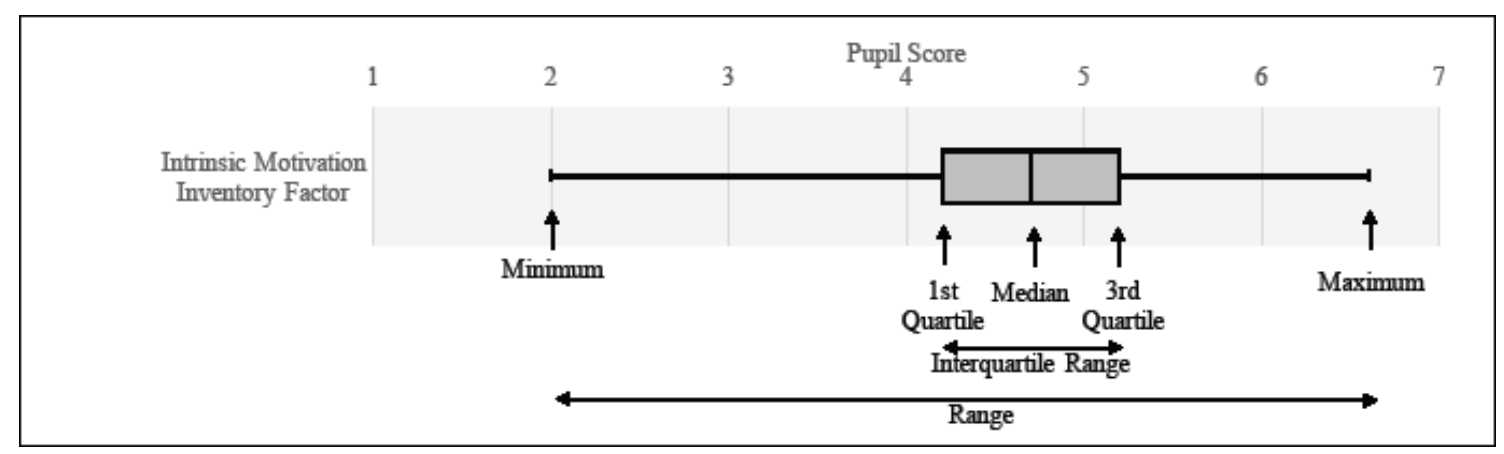


Figure 2. Box plots of calculated pupil IMI scores comparing all pupil scores on before and after questionnaires

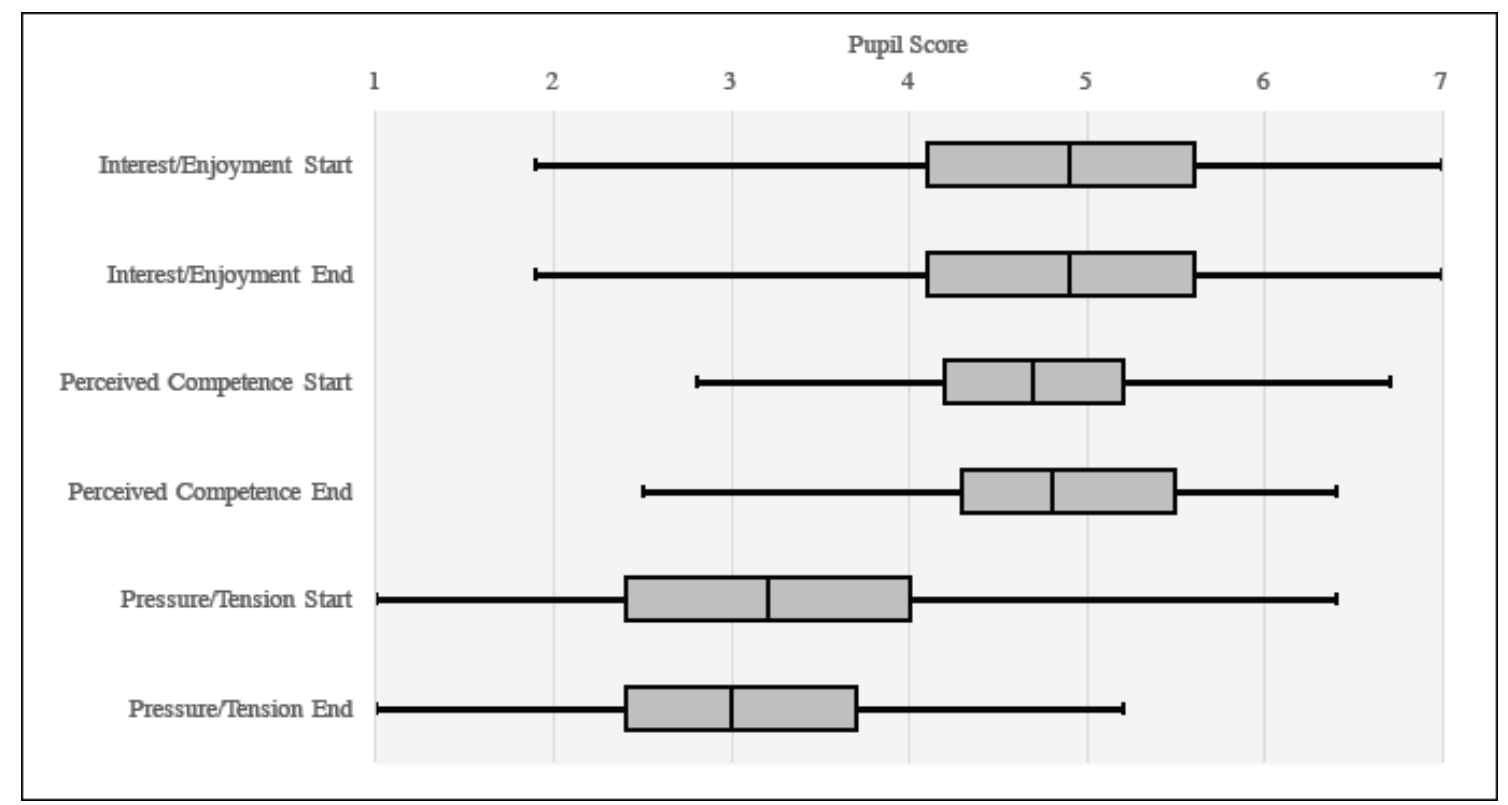


Figure 3. Pupil factor scores for the start of project questionnaire split by gender

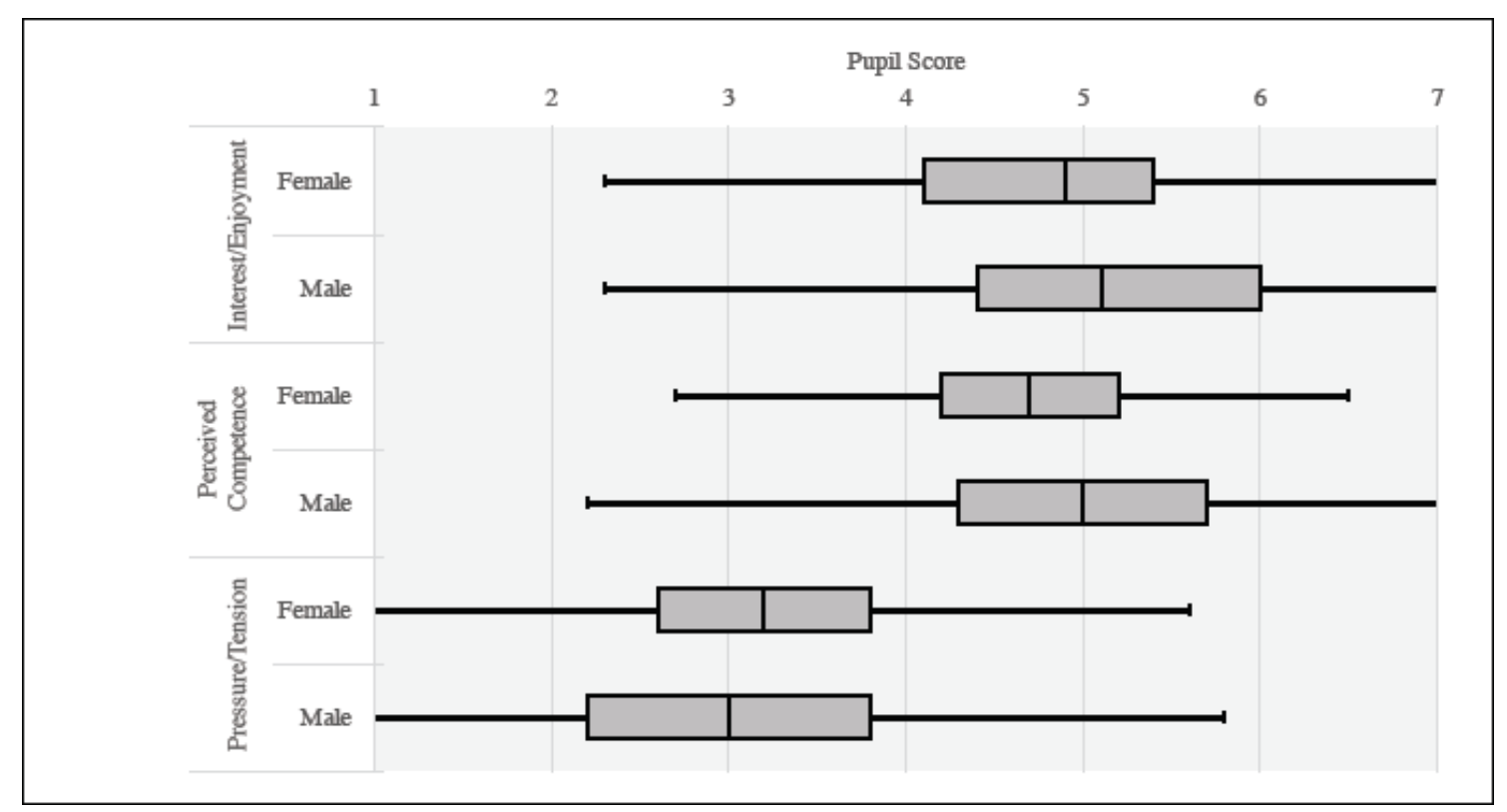

